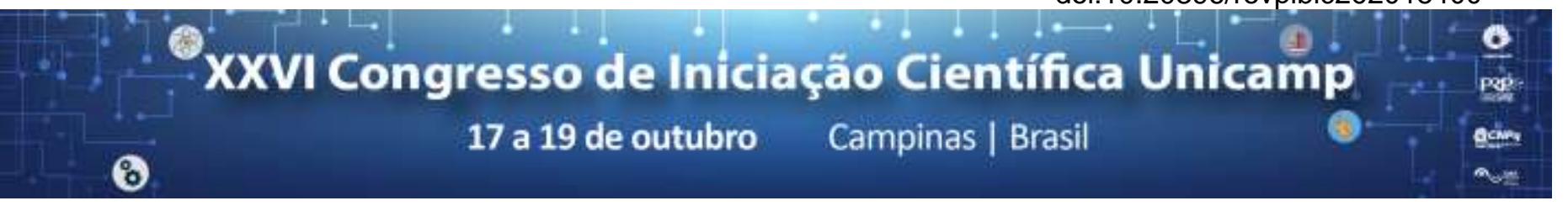

\title{
AVALIAÇÃO EM ESCALA LABORATORIAL E REAL DO USO DE ESGOTO TRATADO NA PRODUÇÃO DE PISOS
}

\section{Fabio Oliveira*, Adriano Luiz Tonetti}

\section{Resumo}

A construção civil é uma grande consumidora de água potável e sofre pressão para a redução deste consumo. Para isso, há a necessidade de pesquisas que visem o uso da água contida nos esgotos sanitários como alternativa sustentável. Logo, este estudo visou o desenvolvimento de processos e técnicas em saneamento e a minimização do uso da água, avaliando o uso do esgoto tratado pela Estação de Tratamento de Esgotos Barão Geraldo (SANASA, Campinas) na produção de pisos intertravados.

\section{Palavras-chave:}

Esgoto, reuso, produção de pisos.

\section{Introdução}

A construção civil é uma grande consumidora de água e sofre pressão para a redução deste consumo. Este setor é responsável pelo consumo de até $75 \%$ dos recursos naturais. No presente estudo procurou-se aumentar a sustentabilidade da produção de pisos intertravados de concreto, utilizando diferentes dosagens de esgoto tratado produzido na Estação de Tratamento de Esgotos Barão Geraldo (SANASA, Campinas). A qualidade deste esgoto foi avaliada quanto a diversos parâmetros, e os corpos de prova e pisos intertravados foram caracterizados para, finalmente, os pisos serem instalados em um trecho do estacionamento da FEC/UNICAMP para análise em escala real.

\section{Resultados e Discussão}

$\mathrm{Na}$ primeira etapa do projeto, o efluente foi coletado e passou por um processo de desinfecção por hipoclorito de cálcio, buscando garantir condições seguras para seu uso na produção. Em seguida, parte desse efluente desinfectado passou por caracterização física, química e biológica para avaliar a qualidade e adequação para ser empregado como água de reuso.

$\mathrm{Na}$ segunda etapa, o efluente tratado foi empregado na produção de corpos de prova cilíndricos (Figura 1). Utilizou-se cimento do tipo CP II, areia média e pedrisco (brita zero), conforme o traço 1:2:3 e relação águacimento de 0,45 . Nas amostras, foi utilizada água com diferentes concentrações de esgoto tratado/água potável.

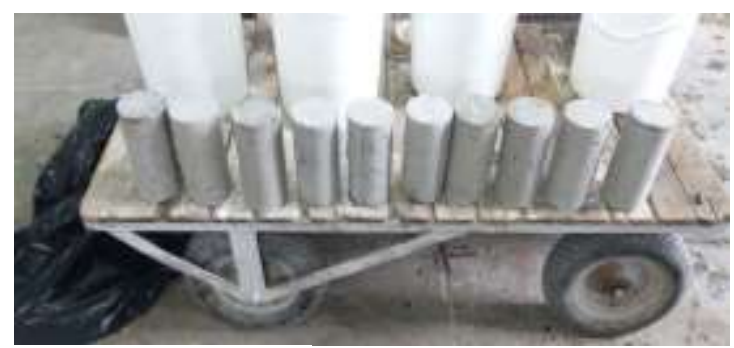

Figura 1: Amostra de corpos de prova fabricados com diferentes composições de água potável e água de reúso.
Fabricados os corpos de provas e transcorridos 30 dias, estes foram submetidos a ensaios para sua caracterização. Para os corpos de prova fabricados com $100 \%$ de água de reuso, a resistência à compressão média foi de $43,88 \mathrm{MPa}$ e a absorção média foi de $3,01 \%$, atendendo aos limites estabelecidos na NBR 9781 Avaliação de peças de concreto para pavimentação.

Tendo em vista os resultados satisfatórios apresentados pelos corpos de prova feitos com água de reuso, fabricaram-se cerca de $4 \mathrm{~m}^{2}$ de pisos intertravados (Figura 2), metade com água de reuso e a outra metade com água potável para comparação.

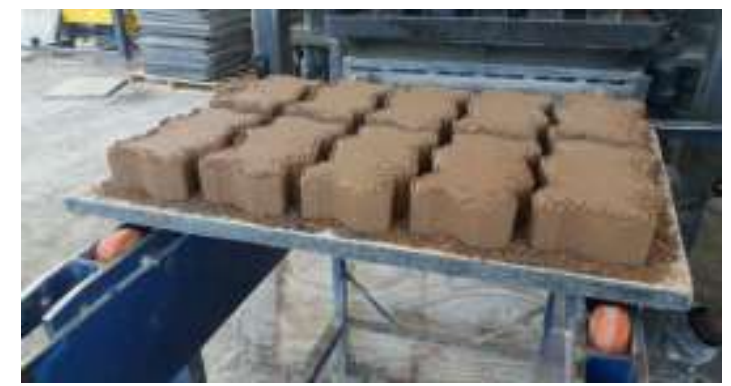

Figura 2: Amostra de pisos intertravados fabricados na empresa Pavicon (Hortolândia-SP).

Os pisos foram submetidos, após 52 dias, a ensaios para sua caracterização. Para os pisos fabricados com água de reuso, a resistência característica à compressão foi de 35,65 MPa e a aborção média de 6,81\%, enquanto que para os moldados com água potável, a resistência característica à compressão foi de $34,83 \mathrm{MPa}$ e a absorção média de $5,74 \%$.

\section{Conclusões}

Tendo em vista os parâmetros obtidos para os pisos intertravados moldados com água de reuso, comparados com os fabricados com água potável e às exigências da NBR 9781, o uso de água de reuso mostrou-se como boa alternativa na redução do consumo de água potável nesse setor da construção civil.

Associação Brasileira de Normas Técnicas - ABNT. NBR 9781: Avaliação de peças de concreto para pavimentação: Métodos de ensaios. Rio de Janeiro, 2013. 